\title{
Metallogenic Fluid Characteristics of Yueshan Cu-polymetallic Deposit
}

\author{
Chenguang Zhang ${ }^{1,2^{*}}$, Haifeng $\mathrm{Hu}^{3}$, Daohan $\mathrm{Zha}^{4}$, Haidong Jiang ${ }^{5}$ \\ ${ }^{1}$ College of Geographic Science, Henan Key Laboratory for Synergistic Prevention of Water and Soil Environmental \\ Pollution, Southern Henan Center for Mineral Rock and Gem-Jade Identification and Processing, Xinyang Normal University, \\ Xinyang 464000, China \\ ${ }^{2}$ Key Laboratory of Metallogenic Prediction of Nonferrous Metals and Geological Environment Monitoring (Central South \\ University), Ministry of Education, Changsha 410083, China \\ ${ }^{3}$ Hunan Geology Exploration Institute of China Chemical Geology and Mine Bureau, Changsha 410004, China \\ ${ }^{4}$ Hunan Key Laboratory of Land Resources Evaluation and Utilization, Changsha 410007, China \\ ${ }^{5}$ Institute of Resources and Environmental Engineering, Guizhou University of Technology, Guiyang 550003, China
}

Corresponding Author Email: paladin@xynu.edu.cn

https://doi.org/10.18280/ijht.370217

Received: 12 January 2019

Accepted: 12 March 2019

\section{Keywords:}

fluid inclusion, hydatogenesis, fluid, temperature

\begin{abstract}
Yueshan Cu-polymetallic deposit Located between the Yangtze Plate, the Qinling-Dabie orogenic belt and is characterized by excellent metallogenic conditions. This paper attempts to disclose the hydatogenesis mechanism of Yueshan $\mathrm{Cu}$-polymetallic deposit. The metallogenic mechanism of material and fluid sources under the action of heat sources was discussed through fluid inclusion analysis. In this way, the physical-chemical conditions and fluid composition of hydatogenesis were determined, revealing the fluid and temperature features of hydatogenesis. It is concluded that the metallogenic fluid of Yueshan $\mathrm{Cu}$ polymetallic deposit belongs to the type of $\mathrm{Na}++\mathrm{Ca} 2++\mathrm{K}++\mathrm{Mg}++\mathrm{Cl}-(\mathrm{SO} 42-)$, and the hot magma fluid was mineralized under $450 \sim 521{ }^{\circ} \mathrm{C}$. Yanshanian magmatic intrusion provided heat source for metallogenic hydrothermal fluid of Yueshan $\mathrm{Cu}$-polymetallic deposit. The fluid activity underwent skarn hydrothermal stage and tectonic hydrothermal stage, and the skarn minerals formed in the early stage were superimposed and enriched.
\end{abstract}

\section{INTRODUCTION}

Located between the Yangtze Plate, the Qinling-Dabie orogenic belt, and the North China Plate, the polymetallogenic belt (copper-iron-gold) in the middle and lower reaches of the Yangtze River is the most important metallogenic belt in eastern China. There are many mining areas in this metallogenic belt. One of them is Yueshan $\mathrm{Cu}-$ polymetallic deposit, which lies close to the southern Anhui city of Anqing [1-5].

Many scholars have explored the basic geology, regional metallogenesis, rock genesis and metallogenic stage of Yueshan mine, yielding fruitful results. In addition, several universities and science institutes, namely, China University of Geoscience and Central South University, have discussed the metallogenic mechanism of Yueshan mine, considering the correlation of metallogenesis with magmatite, strata and geological structure. However, there is little report on the hydatogenesis mechanism of Yueshan mine [6-8].

To make up for the gap, this paper carefully examines minerals collected from Yueshan mine, using optical microscope, Linkam THMSG600 geological hot and cold stage and Dionex DX-120 ion chromatograph. In this contribution, on the basis of identification of ore-forming stages, we investigated fluid sources, physicochemical conditions for mineralization of the Yueshan $\mathrm{Cu}$-polymetallic deposit, combining fluid inclusion study with geological evidence and stable isotopic analysis.

\section{METHODOLOGY}

Ranging from garnet, diopside, quartz to calcite, minerals in different metallogenic stages were tested on Linkam THMSG600 geological hot and cold stage under the temperature of $-196 \sim 600^{\circ} \mathrm{C}$. The instrument precision is $\pm 1^{\circ} \mathrm{C}$ under $10 \sim 600{ }^{\circ} \mathrm{C}$ and $\pm 0.1^{\circ} \mathrm{C}$ under $-196 \sim 0^{\circ} \mathrm{C}$.

During the test, the hot and cold stage was used to measure the following indices of fluid inclusions: the freezing temperature, the initial ice melting temperature, the final ice melting temperature, homogenization temperature and daughter mineral melting temperature. Next, the salinity, density and homogenization pressure of the fluid were computed by the equation from, with the aid of the FLINCOR program [9-14].

\subsection{Microphysiography of fluid inclusions}

In Yueshan Cu-polymetallic deposit, the host minerals of fluid inclusions are garnet, diopside, quartz and calcite. Thus, the micro physiography of these minerals was studied in the samples collected from Yueshan $\mathrm{Cu}$-polymetallic deposit. The micro physiographic features are listed in Table 1 below.

The fluid inclusions in the mine are either protogenetic or epigenetic. There are relatively few inclusions in the deposit, most of which are elliptical or irregular, falling between 6 and $19 \mu \mathrm{m}$. 
Table 1. The microphysiographic features of fluid inclusions

\begin{tabular}{ccccc}
\hline ID & Shape & Kind & Size & GLR \\
\hline \multirow{2}{*}{1} & ellipse, rectangular, & \multirow{2}{*}{ Ia, II } & $11 \mu \mathrm{m}-$ & $15 \%-$ \\
& irregular - shaped & & $52 \mu \mathrm{m}$ & $40 \%$ \\
\multirow{2}{*}{2} & ellipse, rectangular, & II & $6 \mu \mathrm{m}-$ & $15 \%-$ \\
& irregular - shape & & $19 \mu \mathrm{m}$ & $30 \%$ \\
\multirow{2}{*}{3} & ellipse, rectangular, & II & $7 \mu \mathrm{m}-$ & $15 \%-$ \\
& irregular - shape & & $11 \mu \mathrm{m}$ & $30 \%$ \\
\multirow{2}{*}{4} & ellipse, rectangular, & Ia, Ib, & $7 \mu \mathrm{m}-$ & $15 \%-$ \\
& irregular - shape & II & $32 \mu \mathrm{m}$ & $40 \%$ \\
\hline
\end{tabular}

At room temperature, the fluid inclusions in the deposit can be divided into halite crystal-containing multiphase inclusion (type I) and gas-liquid two-phase inclusion (type II), according to the composition, ratio and combination of different phases. Type I inclusions can be further split into two subtypes by the order of disappearance of halite crystal and bubble under heating: subtype Ia (halite crystal disappears first under heating) and subtype $\mathrm{Ib}$ (bubble disappears first under heating). The fluid inclusions observed in our study are all saline systems with little presence of $\mathrm{CO}_{2}$. The micrographs on different minerals in Yueshan $\mathrm{Cu}$ polymetallic deposit are presented in Figure 1 below.
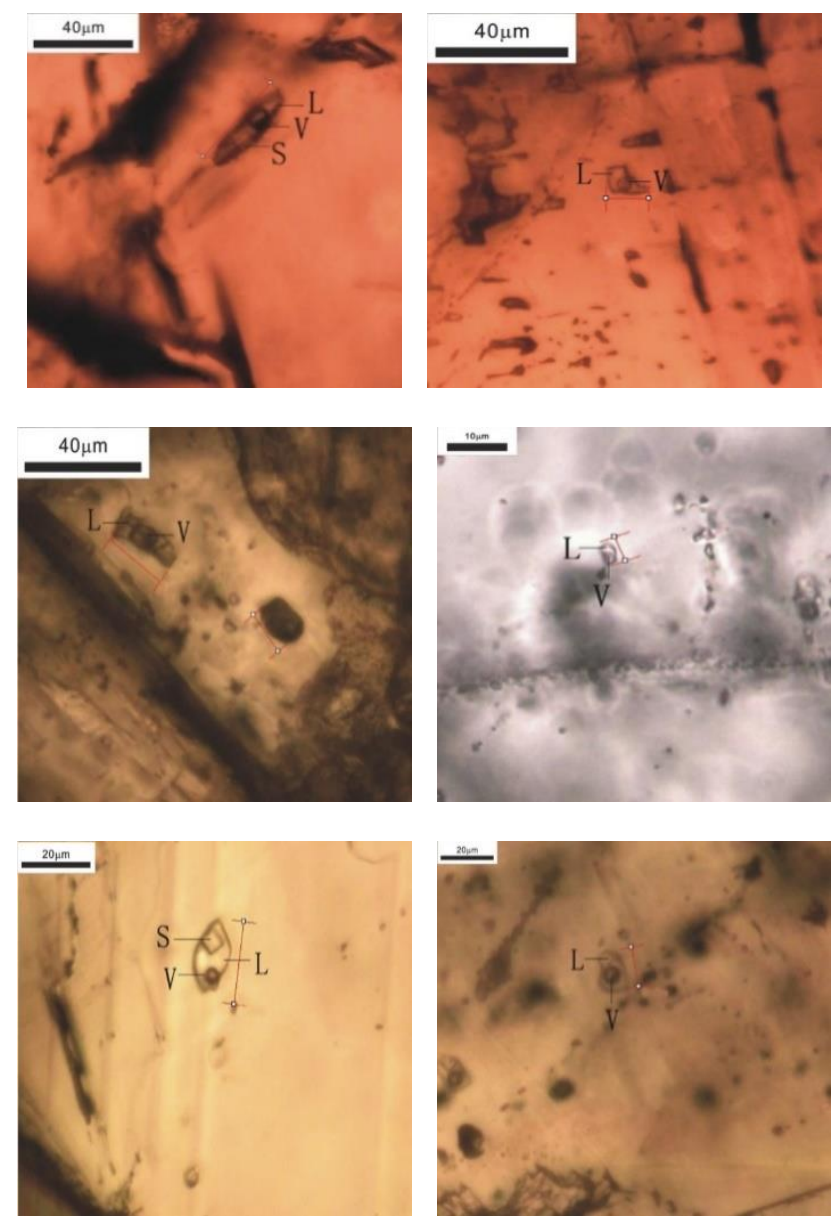

Figure 1. The micrographs on different minerals in Yueshan deposit

(a) Type I inclusions in garnet; (b) Type II inclusions in garnet;

(c) Type II inclusions in diopside; (d) Type II inclusions in quartz;

(e) Type I inclusions in calcite; (f) Type II inclusions in calcite.
As shown in Figure 1, type I inclusions were mainly developed in garnet and calcite. Most subtype Ia inclusions were protogenetic, and produced in garnet and calcite; Ranging between 10 and $30 \mu \mathrm{m}$ in size, subtype Ia inclusions were primarily elliptical or irregular and generated individually, with a gas-liquid ratio of $30 \sim 40 \%$; the halite crystals of subtype Ia inclusions were cubic. Most subtype $\mathrm{Ib}$ inclusion were developed in calcite; Ranging between 8 and $30 \mu \mathrm{m}$ in size, subtype $\mathrm{Ib}$ inclusions were irregular in shape and generated individually, with a gas-liquid ratio of $20 \sim 35 \%$; the halite crystals of subtype Ib inclusions were also cubic. Overall, subtypes Ia and Ib mainly differed in the inclusion morphology under heating, with no significant difference in shape or gas-liquid ratio.

As a common type of inclusions, type II inclusions were observed in garnet, diopside, quartz and calcite. Ranging between 7 and $30 \mu \mathrm{m}$ in size, most type II inclusions were elliptical, elongated or irregular, with a gas-liquid ratio of $15 \% \sim 30 \%$. In a few cases, the gas-liquid ratio could reach $40 \%$.

\subsection{Physical-chemical conditions of fluid inclusions}

The fluid inclusions of garnet, diopside, quartz and calcite were subjected to temperature measurement by freezing and homogenization methods. The measured results are recorded in Table 2. The statistical histograms of homogenization temperature and salinity were plotted through statistical calculations (Figures 2 and 3). The physical-chemical conditions of fluid inclusions were detailed below.

\section{(1) Early skarn stage:}

The fluid inclusions mainly existed in garnet and diopside. Most of the inclusions in garnet belonged to type II, and some belonged to type Ia.

Type II inclusions were all homogeneous to liquid phase at the temperature of $326 \sim 499^{\circ} \mathrm{C}$ (mean: $443^{\circ} \mathrm{C}$ ); the final ice melting temperature was $-19.7 \sim-10.2^{\circ} \mathrm{C}$ (mean: $-14.6^{\circ} \mathrm{C}$ ), corresponding to the salinity of $14.2 \% \sim 22.2 \% \mathrm{NaCleqv}$ (mean: $18.0 \% \mathrm{NaCleqv}$ ) and density of 1.08 1.09 (mean: $0.69)$. Thus, the homogenization pressure was computed as 639 1,066bar.

For type Ia inclusions, the homogenization temperature was $465 \sim 521^{\circ} \mathrm{C}$ (mean: $496^{\circ} \mathrm{C}$ ), corresponding to the salinity of $39.6 \% \sim 42.3 \% \mathrm{NaCleqv}$ (mean: $40.6 \% \mathrm{NaCleqv}$ ) and density of 1.08 1.09 (mean: 1.09). Thus, the homogenization pressure was computed as 1,120 1,593bar.

All inclusions in diopside belonged to type II, and were homogeneous to liquid phase at the temperature of $344 \sim 462^{\circ} \mathrm{C}$ (mean: $324^{\circ} \mathrm{C}$ ); the final ice melting temperature was $-14 \sim-6.7^{\circ} \mathrm{C}$ (mean: $-10.22^{\circ} \mathrm{C}$ ), corresponding to the salinity of $10.10 \% \sim 17.77 \% \mathrm{NaCleqv}$ (mean: $13.97 \% \mathrm{NaCleqv}$ ) and density of $0.67 \sim 0.93$ (mean: 0.84 ). Thus, the homogenization pressure was computed as 207 6,842bar.

\section{(2) Quartz sulfide stage}

The fluid inclusions were mainly developed in quartz. All of them belongs to type II. During the test, type II inclusions were all homogeneous to liquid phase at the temperature of $298 \sim 406^{\circ} \mathrm{C}$ (mean: $344^{\circ} \mathrm{C}$ ); the final ice melting temperature was $-17.2 \sim-8.9^{\circ} \mathrm{C}$ (mean: $-12.79^{\circ} \mathrm{C}$ ), corresponding to the salinity of $12.7 \% \sim 20.4 \% \mathrm{NaCleqv}$ (mean: $16.5 \% \mathrm{NaCleqv}$ ) 
and density of $0.76 \sim 0.91$ (mean: 0.84). Thus, the homogenization pressure was computed as 101 1,237bar.

(3) Carbonate stage
Calcite was the leading host mineral of fluid inclusions. Most inclusions belonged to type II, and some belonged to type I.

Table 2. Measured temperatures of the fluid inclusions in Yueshan mine

\begin{tabular}{|c|c|c|c|c|c|c|c|c|}
\hline ID & & & $1-9 \mathrm{~b}$ & $400-2-9$ & $340-28-1$ & & $700-1-3 b$ & \\
\hline Host mineral & & & net & Diopside & Silica & & Calcite & \\
\hline fluid & & Ia & II & II & II & Ia & $\mathrm{Ib}$ & II \\
\hline $\mathrm{T}\left({ }^{\circ} \mathrm{C}\right)$ & range & & $-56.1 \sim-50.1$ & $-51.3 \sim-70.2$ & $-68.2 \sim-48.6$ & & & $-55.7 \sim-45.3$ \\
\hline $1(C)$ & average & & -53.24 & -58.3 & -58.34 & & & -52.45 \\
\hline $\mathrm{MT}\left({ }^{\circ} \mathrm{C}\right)$ & range & & $-19.7 \sim-10.2$ & $-14 \sim-6.7$ & $-17.2 \sim-8.9$ & & & $-16.5 \sim-9.8$ \\
\hline $\mathrm{MI1}(\mathrm{C})$ & average & & -14.56 & -10.22 & -12.79 & & & -14.28 \\
\hline $\operatorname{DMT}\left({ }^{\circ} \mathrm{C}\right)$ & range & 319 349 & & & & $273 \sim 340$ & $265 \sim 285$ & \\
\hline & average & 330 & & & & 311 & 274 & \\
\hline G-L-U-T $\left({ }^{\circ} \mathrm{C}\right)$ & range & $465 \sim 521$ & $326 \sim 499$ & $344 \sim 462$ & $298 \sim 406$ & $338 \sim 465$ & $218 \sim 312$ & $217 \sim 272$ \\
\hline $\mathrm{G}-\mathrm{L}-\mathrm{U}-1(\mathrm{C})$ & average & 495.8 & 443.3 & 394.2 & 343.9 & 402.3 & 266.6 & 239.8 \\
\hline & range & $39.6 \sim 42.3$ & $14.2 \sim 22.2$ & $10.1 \sim 19.8$ & $12.7 \sim 20.4$ & $36.2 \sim 41.5$ & $35.7 \sim 37.1$ & $18.2 \sim 19.8$ \\
\hline salınity (\%) & average & 40.6 & 18.0 & 14.5 & 16.5 & 39.1 & 36.2 & 17.9 \\
\hline & range & $1.08 \sim 1.09$ & $0.50 \sim 0.91$ & $0.67 \sim 0.93$ & $0.76 \sim 0.91$ & $1.08 \sim 1.10$ & $1.10 \sim 1.15$ & $0.95 \sim 0.96$ \\
\hline density $\left(\mathrm{g} / \mathrm{cm}^{3}\right)$ & average & 1.09 & 0.69 & 0.84 & 0.84 & 1.09 & 1.11 & 0.96 \\
\hline & range & $112 \sim 159$ & $64 \sim 107$ & $21 \sim 68$ & $10 \sim 124$ & $146 \sim 219$ & $60 \sim 165$ & $45 \sim 56$ \\
\hline Uniform pressure (MPa) & average & 142 & 76 & 45 & 75 & 174 & 90 & 52 \\
\hline
\end{tabular}

All type II inclusions were homogeneous to liquid phase at the temperature of $3,266 \sim 499^{\circ} \mathrm{C}$ (mean: $443^{\circ} \mathrm{C}$ ); the final ice melting temperature was $-16.5 \sim-9.8^{\circ} \mathrm{C}$ (mean: $-14.3^{\circ} \mathrm{C}$ ), corresponding to the salinity of $18.2 \% \sim 19.8 \% \mathrm{NaCleqv}$ (mean: $17.9 \% \mathrm{NaCleqv}$ ) and density of $0.95 \sim 0.96$ (mean: 0.96). Thus, the homogenization pressure was computed as 451 559bar.

For type Ia inclusions, the homogenization temperature was $338 \sim 465^{\circ} \mathrm{C}$ (mean: $402.30^{\circ} \mathrm{C}$ ), corresponding to the salinity of $36.2 \% \sim 41.5 \% \mathrm{NaCleqv}$ (mean: $39.1 \% \mathrm{NaCleqv}$ ) and density of 1.08 1.10 (mean: 1.09). Thus, the homogenization pressure was computed as 1,457 2,188bar.

For type $\mathrm{Ib}$ inclusions, the homogenization temperature was $218 \sim 312^{\circ} \mathrm{C}$ (mean: $267^{\circ} \mathrm{C}$ ), corresponding to the salinity of $35.7 \% \sim 37.1 \% \mathrm{NaCleqv}$ (mean: $36.2 \% \mathrm{NaCleqv}$ ) and density of 1.08 1.09 (mean: 1.09). Thus, the homogenization pressure was computed as 601 1,654bar.

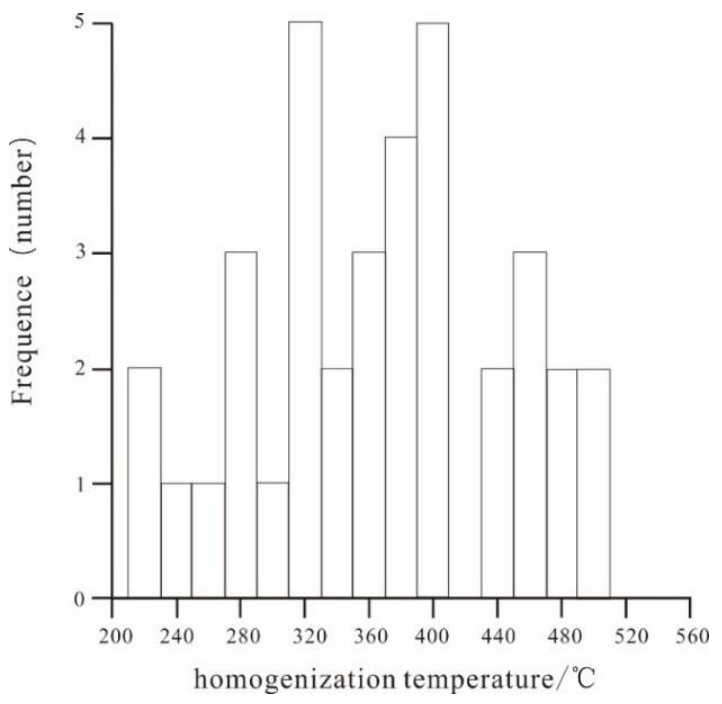

Figure 2. Statistical histogram of homogenization temperature of fluid inclusions

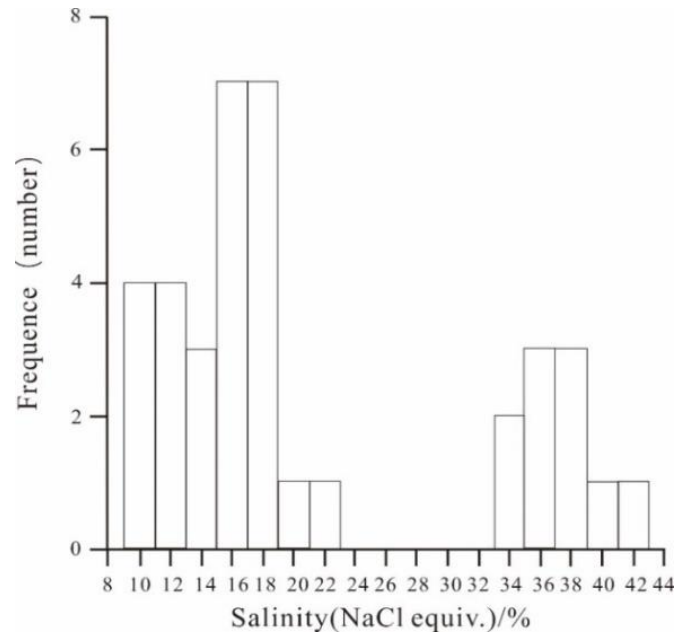

Figure 3. Statistical histogram of salinity of fluid inclusions

\subsection{Composition of fluid inclusions}

The minerals (single mineral purity $>98 \%$ ) like garnet, magnetite, pyrite, quartz and calcite were selected, and subjected to group composition analysis on Dionex DX-120 ion chromatograph. The test results are listed in Tables 3 and 4.

It can be seen from Tables 3 and 4 that, in the liquid phase of fluid inclusions in Yueshan deposit, the main cations were $\mathrm{Ca}^{2+}, \mathrm{Na}^{+}, \mathrm{K}^{+}$and $\mathrm{Mg}^{2+}$, whose contents were $30.111 \sim 96.256 \times 10^{-6}, \quad 1.406 \sim 15.729 \times 10^{-6}, \quad 1.592 \sim 6.998 \times 10^{-}$ 6 and $7.191 \sim 11.448 \times 10^{-6}$, respectively. The abundance of $\mathrm{Ca}^{2+}$ in the metallogenic fluid is attributable to the water-rock interaction between the fluid and the carbonate. Meanwhile, the main anions include $\mathrm{SO}_{4}{ }^{2-}\left(43.981 \sim 117.831 \times 10^{-6}\right)$ and $\mathrm{Cl}^{-}$ $\left(5.785 \sim 37.169 \times 10^{-6}\right)$, plus a slight amount of $\mathrm{F}^{-}$. In the gas phase of the fluid inclusions, the content of $\mathrm{H}_{2} \mathrm{O}$ was far greater than that of any other gas phase component. In addition, the inclusions had a high presence of $\mathrm{CO}_{2}$, a certain amount of $\mathrm{CH}_{4}$ and traces of $\mathrm{C}_{2} \mathrm{H}_{2}, \mathrm{H}_{2}$ and $\mathrm{C}_{2} \mathrm{H}_{6}$. 
Table 3. Liquid phase composition of fluid inclusions in Yueshan $\mathrm{Cu}$-polymetallic deposit

\begin{tabular}{ccccccccc}
\hline \multirow{2}{*}{ ID } & \multirow{2}{*}{ Object } & \multicolumn{7}{c}{ Liquid compositions $\left(10^{-6}\right)$} \\
\cline { 3 - 9 } & & $\mathrm{F}^{-}$ & $\mathrm{Cl}^{-}$ & $\mathrm{SO}_{4}^{2-}$ & $\mathrm{Na}^{+}$ & $\mathrm{K}^{+}$ & $\mathrm{Mg}^{2+}$ & $\mathrm{Ca}^{2+}$ \\
\hline 1 & Garnet & 3.367 & 15.475 & 117.831 & 4.381 & - & 11.448 & 96.256 \\
2 & Magnetite & 2.763 & 5.785 & 71.260 & 1.406 & - & - & 66.000 \\
3 & Pyrite & 4.513 & 37.169 & 43.981 & 15.729 & 6.998 & - & 39.945 \\
4 & Silica & 5.345 & 28.682 & 55.707 & 8.309 & 2.049 & 7.197 & 42.837 \\
5 & Calcite & 2.728 & 7.641 & 15.471 & 3.328 & 1.592 & - & 30.111 \\
\hline
\end{tabular}

Table 4. Gas phase composition of fluid inclusions in Yueshan Cu-polymetallic deposit

\begin{tabular}{ccccccccc}
\hline \multirow{2}{*}{ ID } & \multirow{2}{*}{ Object } & \multicolumn{7}{c}{ Gas - phase components $\left(10^{-6}\right)$} \\
\cline { 3 - 8 } & & $\mathrm{H}_{2}$ & $\mathrm{CH}_{4}$ & $\mathrm{C}_{2} \mathrm{H}_{2}$ & $\mathrm{CO}_{2}$ & $\mathrm{C}_{2} \mathrm{H}_{6}$ & $\mathrm{H}_{2} \mathrm{O}$ & $\mathrm{CO}_{2} / \mathrm{H}_{2} \mathrm{O}$ \\
\hline 1 & Garnet & 1.196 & 17.957 & - & 191.874 & - & 932 & 0.206 \\
2 & Magnetite & 0.597 & 16.591 & - & 116.723 & - & 652 & 0.179 \\
3 & Pyrite & 2.044 & 28.764 & - & 84.299 & 8.124 & 413 & 0.204 \\
4 & Silica & 3.289 & 21.468 & - & 214.611 & - & 1321 & 0.162 \\
5 & Calcite & 0.643 & 6.680 & - & 54.775 & - & 933 & 0.059 \\
\hline
\end{tabular}

\section{METALLOGENIC MECHANISM}

Based on the test on fluid inclusions, this chapter investigates the material, fluid and heat sources of hydatogenesis.

\subsection{Material sources}

\section{(1) Copper and iron sources}

Judging by the ore-bearing potential, the local strata contain little metallogenic materials. It is deduced that the metallogenic elements $\mathrm{Cu}$ and $\mathrm{Fe}$ of Yueshan deposit mainly come from magma, according to the geological features of the deposit and the geochemical features of the rocks. The metallogenic parent rock is the diorite-bearing Yueshan rock mass, which is closely related to metallogenesis. The target deposit lies at the front end of the rock mass. The deep mantle is the source for the original magma of the rock mass. The deep-source magma contains lots of metallogenic elements like $\mathrm{Cu}$ and $\mathrm{Fe}$, laying the basis for the enrichment of such elements.

\section{(2) Sulfur sources}

The author conducted sulfur isotope tests on ores, surrounding rock and rock mass. The results show that the $\delta^{34} \mathrm{~S}_{\mathrm{CDT}}$ values of ores were discrete, falling in $11.3 \times 10^{-3} \sim+19.2 \times 10^{-3}$. Hence, the sulfur of Yueshan mine has mainly sources, such as deep-source magma, bio-sulfur in the strata and the sulfur in the gypsum-salt layer, rather than a single source.

\subsection{Fluid sources}

The gas-liquid phase analysis on garnet and magnetite of Yueshan mine indicates that the liquid inclusions had a high content of $\mathrm{H}_{2}$, indicating that the metallogenic fluid must come from deep source(s).

The liquid phase saw high contents of $\mathrm{SO}_{4}{ }^{2-}, \mathrm{Cl}^{-}, \mathrm{F}^{-}, \mathrm{Ca}^{2+}$, $\mathrm{Na}^{+}, \mathrm{K}^{+}$and $\mathrm{Mg}^{2+}$. Among them, the heavy presence of $\mathrm{Ca}^{2+}$ and $\mathrm{Mg}^{2+}$ may be the result of the carbonate surrounding rock of Yueshan deposit. During the evolution of metallogenic fluid, the crust components must have been assimilated with the surrounding rock. The existence of $\mathrm{Na}^{+}$and $\mathrm{Cl}^{-}$in the fluid was confirmed by the small amount of salt crystals observed under the microscope in some inclusions.

Through microscope observation and gas phase analysis, it is learned that $\mathrm{H}_{2} \mathrm{O}$ and $\mathrm{CO}_{2}$ were important components in metallogenic fluid. The two components always dominated the fluid, either in gas form or liquid form, although the inclusions exhibited different features in different metallogenic stages.

\subsection{Heat sources}

The scatterplots of homogenization temperature and salinity in liquid inclusions of Yueshan deposit are displayed in Figure 4. The two highlighted regions in the figure are the medium and high ranges of the homogenization temperature, which concentrated between 271 and $521^{\circ} \mathrm{C}$.

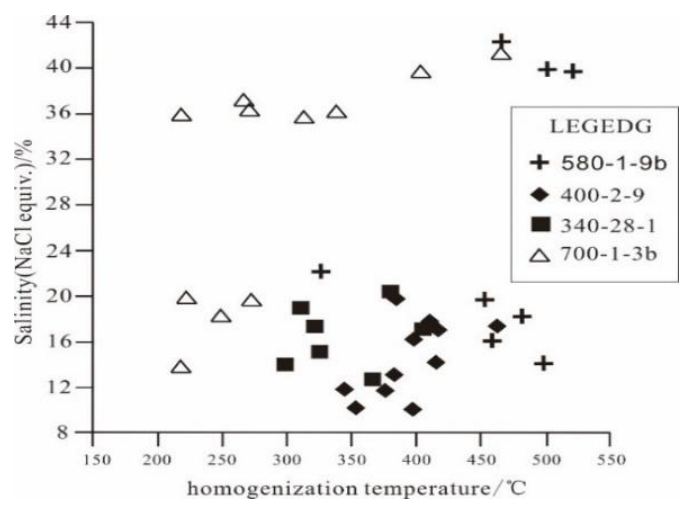

Figure 4. The scatterplots of homogenization temperature and salinity in liquid inclusions of Yueshan $\mathrm{Cu}$-polymetallic deposit

The mineral $580-1-9 \mathrm{~b}$ belonged to the high temperature range of $450 \sim 521^{\circ} \mathrm{C}$. The homogenization temperature of the mineral was greater than $450^{\circ} \mathrm{C}$. Most of its liquid inclusions were type II, and a few were type Ia. This composition demonstrates the boiling effect of the metallogenic fluid in the early stage, when the metallogenic temperature equals the minimum temperature $450^{\circ} \mathrm{C}$. This stage corresponds to the skarn stage of the skarnization hydatogenesis period. Under the high metallogenic temperature, the main products were skarn minerals like garnet and diopside. For minerals 340-281 and $700-1-3 b$, the homogenization temperatures of their 
fluid inclusions were mostly within the low to medium range of $200 \sim 320^{\circ} \mathrm{C}$. Due to faulting and other tectonic activities, the hot and pressurized fluid was suddenly depressurized, resulting in boiling at reduced pressure. Thus, $\mathrm{CO}_{2}$ was separated from the hot fluid. According to Williams and Ferreira (1989), $\mathrm{CO}_{2}$ was originally fully mixed with the metallogenic fluid deep in the mantle; when the fluid intruded to the shallow crust, a large amount of $\mathrm{CO}_{2}$ was separated from the fluid due to the plunge in solubility, leading to retrograde metamorphism and copper mineralization. This stage corresponds to the sulfide stage of the skarnization hydatogenesis period through the late stage tectonic hydatogenesis period. All kinds of metal sulfides were produced at this stage, and nonmetallic minerals were mainly quartz and calcite. At the same time, the fluid enriched the skarn minerals formed in the earlier stage. The Yanshanian magmatism intrusion is the major provider of both metallogenic materials and metallogenic fluid, making it the leading cause of metallogenesis in Yueshan mine. The main heat sources are the heat radiation of the ascending metallogenic fluid from the deep mantle, and exothermic reactions in the movement of metallogenic fluid.

\section{CONCLUSIONS}

After analyzing the test results on fluid inclusions, it is concluded that the metallogenic fluid of Yueshan deposit belongs to the type of $\mathrm{Na}^{+}+\mathrm{Ca}^{2+}+\mathrm{K}^{+}+\mathrm{Mg}++\mathrm{Cl}-(\mathrm{SO} 42-)$, and the hot magma fluid was mineralized under $450 \sim 521^{\circ} \mathrm{C}$. Yanshanian magmatic intrusion provided heat source for metallogenic hydrothermal fluid of Yueshan $\mathrm{Cu}$-polymetallic deposit. The fluid activity underwent skarn hydrothermal stage and tectonic hydrothermal stage, and the skarn minerals formed in the early stage were superimposed and enriched.

\section{ACKNOWLEDGMENT}

This research was Funded by: the Key Scientific and Technological Research Project of Henan Province (192102310268); the Open Research Fund Program of Key Laboratory of Metallogenic Prediction of Nonferrous Metals and Geological Environment Monitoring (Central South University), Ministry of Education(2019YSJS08) and the Nanhu Scholars Program for Young Scholars of XYNU; the special projects for promoting the development of big data of Guizhou Institute of Technology; the Geological Resources and Geological Engineering, Guizhou Provincial Key Disciplines, China (ZDXK [2018]001).

\section{REFERENCES}

[1] Liu, L.M., Wan, C.L., Zhao, C.B., Zhao, Y.L. (2011). Geodynamic constraints on orebody localization in the Anqing Orefield, China: Computational modeling and facilitating predictive exploration of deep deposits. Ore Geology Reviews, 43(1): 249-263. https://doi.org/10.1016/j.oregeorev.2011.09.005

[2] Yang, G.S., Yan, Y.F., Feng, P.Y. (2013). Ore-forming fluid system of the Anqing $\mathrm{Cu}-\mathrm{Fe}$ deposit, Anhui Province, China. Advanced Materials Research, 734737:

$135-138$
https://doi.org/10.4028/www.scientific.net/AMR.734737.135

[3] Yang, G. (2015). Magmatic-fluid-metallogenic system of the Anqing skarn $\mathrm{Cu}-\mathrm{Fe}$ deposit, Anhui province, China. Acta Geologica Sinica, 88(s2): 1705-1707. https://doi.org/10.1111/1755-6724.12385_52

[4] Gu, H., Duan, L., Yang, X. (2015). Zircon U-Pb geochronology and hf isotopic geochemistry of the Liwan cu-Mo deposit, Guichi ore cluster field. Acta Geologica Sinica, 88(s2): 1607-1608. https://doi.org/10.1111/1755-6724.12385_7

[5] Duan, L.A., Gu, H.L., Yang, X.Y., Yan, Z.Z. (2015). Chronology and $\mathrm{Hf}$ isotopic study of igneous rocks in the Liwan Cu-polymetal deposit in Guichi along the Middle-Lower Yangtze River. Acta Petrologica Sinica, 31(7): 1943-1961.

[6] Duan, L.A., Gu, H.L., Yang, X.Y. (2017). Geological and geochemical constraints on the newly discovered Yangchongli gold deposit in Tongling region, lower Yangtze metallogenic belt. Acta Geologica Sinica, 91(6): 2078-2108. https://doi.org/10.3969/j.issn.10009515.2017.06.009

[7] Liu, Z.F., Shao, Y.J., Shu, Z.M., Peng, N.H., Xie, Y.L., Zhang, Y. (2012). Fluid inclusion characteristics of Longmenshan copper-polymetallic deposit in Yueshan, Anhui Province, China. Journal of Central South University, 19(9): 2627-2633. https://doi.org/10.1007/s11771-012-1320-y

[8] Zhou, T.F., Yu, F., Feng, Y., Zhang, L.J., Qian, B., Ma, L., Yang, X.F., David, R.C. (2011). Geochronology and significance of volcanic rocks in the Ning-Wu Basin of China. Science China Earth Sciences, 54(2): 185-196. https://doi.org/10.1007/s11430-010-4150-5

[9] Brown, P.E. (1989). FLINCOR: A microcomputer program for the reduction and investigation of fluid inclusion data. American Mineralogist, 74: 1390-1393.

[10] Serttikul, C., Datta, A.K., Rattanadecho, P. (2019). Effect of layer arrangement on 2-D numerical analysis of freezing process in double layer porous packed bed, International Journal of Heat and Technology, 37(1): 273-284. https://doi.org/10.18280/ijht.370133

[11] Wei, Y., Wang, L., Yang, G.S. (2018). Temperature field distribution of a freeze sinking shaft under seepage conditions in cretaceous formation of Western China, International Journal of Heat and Technology, 36(3): 1055-1060. https://doi.org/10.18280/ijht.360336

[12] Abourabia, A.M., Abdel, Moneim, S.A. (2019). Analytical solution of sea water steady magnetohydrodynamic equations subjected to stretching sheet under induced magnetic field and heat transfer, Mathematical Modelling of Engineering Problems, 6(1): 141-151. https://doi.org/10.18280/mmep.060119

[13] Ike, C.C. (2018). Energy formulation for flexural torsional buckling of thin-walled column with open cross- section, Mathematical Modelling of Engineering Problems, 5(2): 58-66. https://doi.org/10.18280/mmep.050202

[14] Brown, P.E., Lamb, W. (1989). M.P-V-T properties of fluids in the system $\mathrm{H}_{2} \mathrm{O}-\mathrm{CO}_{2}-\mathrm{NaCl}$ : New graphical presentations and implications for fluid inclusion studies. Geochimicaet Cosmochimica Acta, 53(6): 1209-1221. 7037(89)90057-4 